\title{
Cardiac Cell Therapies for the Treatment of Acute Myocardial Infarction: A Meta-Analysis from Mouse Studies
}

\author{
Cajetan Immanuel Langa,b Markus Wolfienc Anne Langenbach ${ }^{\mathrm{a}}$ Paula Müller \\ Olaf Wolkenhauerc,d Arash Yavarie,f,g Hüseyin Ince ${ }^{a}$ Gustav Steinhoffb,j \\ Bernd Joachim Krause $^{h}$ Robert David ${ }^{b j}$ Änne Glass ${ }^{i}$
}

aDepartment of Cardiology, University Hospital Rostock, ${ }^{b}$ Reference and Translation Center for Cardiac Stem Cell Therapy, University of Rostock, Rostock, 'Department of Systems Biology and Bioinformatics, University of Rostock, Rostock, Germany; ${ }^{\mathrm{d} S t e l l e n b o s c h}$ Institute of Advanced Study, Wallenberg Research Centre at Stellenbosch University, Stellenbosch, South Africa; experimental Therapeutics,

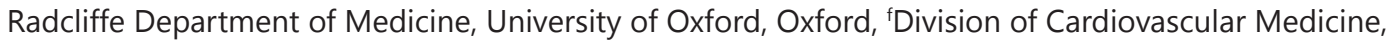
Radcliffe Department of Medicine, University of Oxford, Oxford, 9The Wellcome Trust Centre for Human

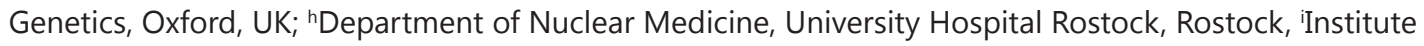
for Biostatistics and Informatics in Medicine and Ageing Research, University Hospital Rostock, Rostock, ${ }^{j}$ Department Life, Light and Matter of the Interdisciplinary Faculty at Rostock University Rostock, Rostock, kDepartment of Anaesthesia and Intensive Care Medicine, University Hospital Rostock Germany

\section{Key Words}

Heart $•$ Stem cell therapy $\bullet$ Mouse $\cdot$ Meta-analysis

\begin{abstract}
Aims: Stem cell-based regenerative therapies for the treatment of ischemic myocardium are currently a subject of intensive investigation. A variety of cell populations have been demonstrated to be safe and to exert some positive effects in human Phase I and II clinical trials, however conclusive evidence of efficacy is still lacking. While the relevance of animal models for appropriate pre-clinical safety and efficacy testing with regard to application in Phase III studies continues to increase, concerns have been expressed regarding the validity of the mouse model to predict clinical results. Against the background that hundreds of preclinical studies have assessed the efficacy of numerous kinds of cell preparations - including pluripotent stem cells - for cardiac repair, we undertook a systematic re-evaluation of data from the mouse model, which initially paved the way for the first clinical trials in this field. Methods and Results: A systematic literature screen was performed to identify publications reporting results of cardiac stem cell therapies for the treatment of myocardial ischemia in the mouse model. Only peer-reviewed and placebo-controlled studies using magnet resonance imaging (MRI) for left ventricular ejection fraction (LVEF) assessment were included. Experimental data from 21 studies involving 583 animals demonstrate a significant improvement in LVEF of 8.59\%

C.I. Lang, M. Wolfien, R. David and Änne Glass contributed equally to this work.


+/- 2.36; $p=.012$ (95\% CI, 3.7-13.8) compared with control animals. Conclusion: The mouse is a valid model to evaluate the efficacy of cell-based advanced therapies for the treatment of ischemic myocardial damage. Further studies are required to understand the mechanisms underlying stem cell based improvement of cardiac function after ischemia.

(C) 2017 The Author(s)

Published by S. Karger AG, Basel

\section{Introduction}

Despite rapid advancements in both pharmacological and interventional treatment options, coronary heart disease remains the most common cause of death in Europe accounting for 1.8 million deaths each year [1]. The quest for new therapeutic approaches to prevent adverse myocardial remodelling post-infarction and limit the subsequent development of irreversible heart failure gave rise to the field of cardiac stem cell therapy. Pivotal trials rapidly pushed stem cell therapies from bench to bedside, with small animal models in particular - namely mice and rats - serving as the basis for safety and efficacy testing [2-4].

Since the first patient was treated with intracoronary infusion of bone marrow stem cells in 2001 [2], numerous Phase I and Phase II studies have repeatedly shown the safety and feasibility of various cardiac stem cell therapies [5]. While these studies proved the excellent safety profile of the tested cell products, there still remains a paucity of data on efficacy because of the small numbers of patients included and the lack of statistical power. Accordingly, several groups are currently recruiting patients for Phase III clinical trials aiming to robustly address the issue of clinical efficacy of stem cell therapy for myocardial repair. [6] (NCT01768702, NCT02059512, NCT01569178)

Until now, clinical trials have largely utilised cell types from the bone marrow that are readily available. These do not necessarily reflect stem cell populations with high potential to regenerate myocardium, however [7]. Accordingly, pluripotent stem cells have been intensively investigated as a source for the generation of cardiomyocytes [8], cells of the conduction system [9] or cardiovascular progenitors [10]. Clinical translation of these highly advanced cell products requires new methods for appropriate safety and efficacy testing with regard to application in patients. The role of animal models to meet these requirements and ensure a full understanding of the biology of stem cell-based therapies is substantially and continually increasing [11].

Due to similarities in heart rate, anatomical and physiological parameters, large animal models have been advocated as superior to rodents in their ability to predict the results of clinical studies in cardiac regeneration $[11,12]$. To our knowledge, however, there is no conclusive evidence supporting the contention that large animal models are superior to rodents - particularly mice - for efficacy testing of cardiac stem cell therapies.

Against the background that the mouse model is cost-effective, readily genetically modified and that over 25 years of experience in the field of murine embryonic stem cell research exists, we performed a meta-analysis to assess the validity of mouse models to predict improvement in left ventricular ejection fraction (LVEF) in clinical trials of regenerative stem cell therapy. To ensure comparability, we included only controlled studies, which assessed LVEF as a surrogate parameter for efficacy using magnetic resonance imaging (MRI), representing the gold standard for assessment of LVEF in humans.

\section{Materials and Methods}

Search strategy

Articles published on Medline between January 1980 and October 2015 were searched via PubMed using the following search terms: TERM A: “(Mouse) AND (stem cells OR progenitor cells OR bone marrow OR mesenchymal OR hematopoietic) AND (myocardial infarction OR cardiac repair OR myocardial regeneration)" and TERM B: "(Mouse) AND (stem cells OR progenitor cells OR bone marrow OR mesenchymal 


\section{Cellular Physiology Cell Physiol Biochem 2017;42:254-268 \begin{tabular}{ll|l} 
DOI: 10.1159/000477324 & O 2017 The Author(s). Published by S. Karger AG, Basel \\
www.karger.com/cpb
\end{tabular}}

Lang et al.: Meta-Analysis: Cardiac Stem Cell Therapies in Mice

OR hematopoietic) AND (myocardial infarction OR cardiac repair OR myocardial regeneration) AND (MRI)". Only English, peer-reviewed and published reports were included. The retrieved studies were carefully examined to exclude potentially duplicate or overlapping data.

\section{Eligibility criteria: Inclusion/exclusion of articles}

The abstracts of all studies retrieved by the above mentioned search terms were reviewed. Whenever the respective abstract did not provide enough data for a decision based on our predefined eligibility criteria (Fig. 1), the material and methods section was carefully studied.

\section{Data abstraction}

The following information was extracted from complete manuscripts of eligible studies: basal characteristics of the study and LVEF. If necessary, data were estimated from graphics or recalculated by available data [13]. Standard deviations were determined or recalculated from standard errors and vice versa. In the final analysis, only studies using MRI for the assessment of LVEF were included. Data derived by echocardiography, nuclear imaging, or pressure-volume loops were excluded. In cases of missing data, corresponding authors were contacted, with two authors from six separate manuscripts responding [13].

\section{Data analysis}

For the first time, we performed a random effects meta-analysis and fixed effects meta-regression analysis that included all available data on Medline regarding cardiac stem cell therapies post-acute myocardial infarction (MI) or in the setting of chronic myocardial ischemia in mice meeting our eligibility criteria. Our primary effect size was the difference in mean LVEF (reported in \%) at follow up between control and treated animals. Both groups underwent MI induction. In the case of multiple measurements over time, data measured at the longest duration of follow up were used for analysis. Only data within the range of one to six weeks after cell application were included.

We have compared numerous statistical models and chosen the maximum-likelihood (ML) estimator [14] to conduct our random effects meta-analysis model. The subsequently obtained continuous variables are reported as weighted mean differences (calculated via the weighted least square algorithm), together with 95\% confidence interval (CI), between cell-treated mice and control groups. Our choice to use the ML estimator rather than the restricted maximum-likelihood (REML) is based on the credibility interval of ML which is the same as the REML interval, but where ML covers the effects of nuisance parameters [15].

Overall homogeneity of differences in mean LVEF of single studies was evaluated based on Cochrane's chi-squared test and the estimator $\tau^{2}$. As described in Higgins et al. [16] heterogeneity was considered significant at $\mathrm{p}<.1$. Inconsistency was estimated by using the $\mathrm{I}^{2}$ statistic; values of $25 \%, 50 \%$, and $75 \%$ were considered low, moderate, and high inconsistency, known respectively as "Higgins rule of Thumb" [16].

Using meta-regression analysis, the following subgroup analyses were performed: cell type (embryonic stem cells (ESC), mesenchymal stem cells (MSC), adult mesodermal cells (MC) and cardiovascular cells $(\mathrm{CVC})$ ), cell origin (autologous, heterologous, xenogeneic), number of injected cells $\left(1-4^{*} 10^{5} ; 0.5-3^{*} 10^{6}\right)$, number of injections (1-2; 3-4), measurement time points (1-3 weeks; >3 weeks), gender of recipient (female or male) and the injected cell types (human, mice).

Funnel plots, Egger's weighed regression and "the trim and fill method" of Duval et al. [17] were used to detect potential publication bias [18].

All analyses were performed with $R$ (Version 3.2.0). In particular, the meta-analysis was performed with the metafor package [19] and the statistical tests and power analysis were computed by using the pwr package [20].

\section{Results}

Electronic searching identified 1,394 publications. After review of the respective abstracts - and where necessary the material and methods section $-1,226$ articles were excluded. Assessment of the remaining 228 papers resulted in 38 articles for detailed evaluation, including supplemental material. A final 21 studies involving 583 animals were identified to meet pre-specified inclusion criteria (Fig. 1). Our restrictive selection strategy 
Fig. 1. Flow-chart illustrating the selection process for included studies. Only studies using unmodified stem cell injections into the heart of mice and which employed MRI for LVEF assessment were considered. i.a. - intra arterial, i.v. - intravenous, i.o. - intraosseous.

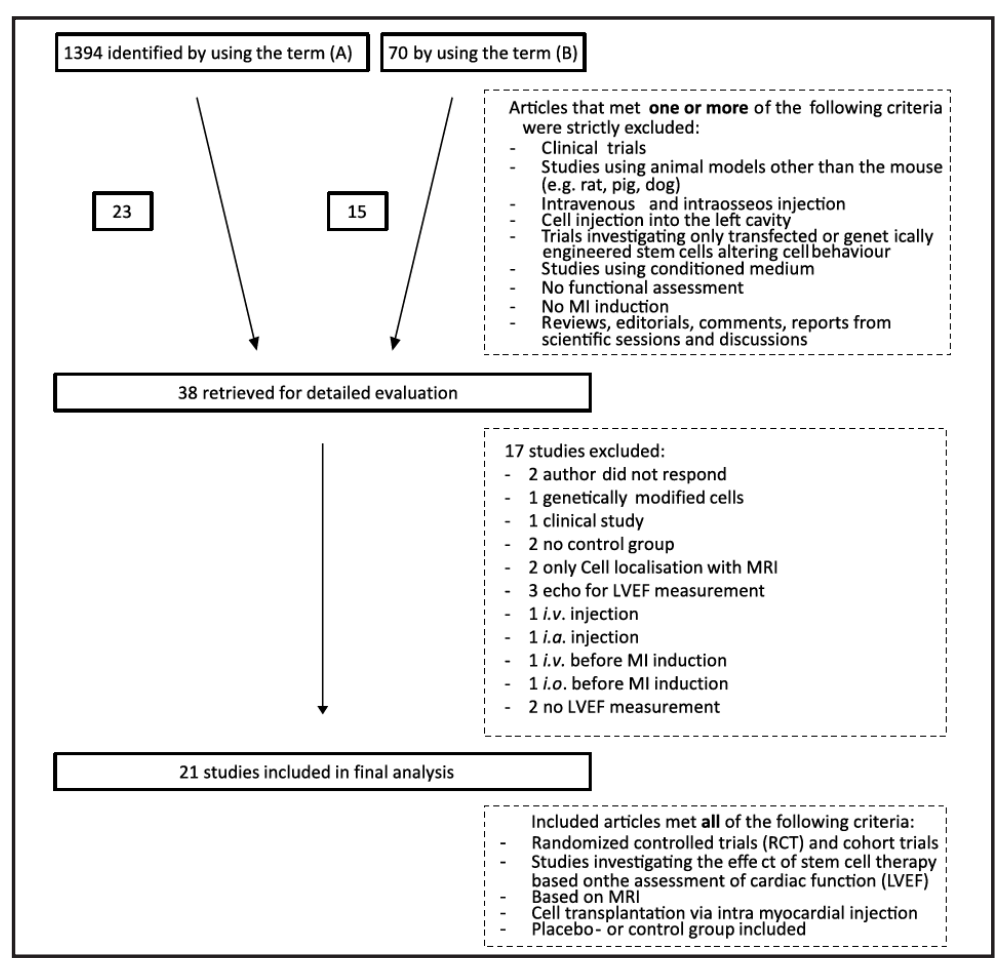

aimed to identify a comparable group of controlled studies all using the same modality for LVEF assessment, a key consideration given the small size of the murine heart.

\section{Study characteristics}

A total of 583 mice from 21 studies containing 34 groups for comparison of the primary endpoint (LVEF) were included in the meta-analysis. All studies were published between 2006 and 2015. Only young adult animals, aged 8 to 16 weeks, were used. Myocardial infarction was induced by surgical permanent occlusion of the left anterior descending artery (LAD) in 28 groups and by surgical cryo-injury in one group. 100,000 to 3,000,000 cells suspended in saline, PBS or medium were injected directly into the myocardium using a syringe, constituting 5 - 30 $\mu$ l applied via 1 - 5 single injections. More details are provided in Table 1. Treated animals received cell suspensions, whereas control animals received saline, PBS or medium (suspending agent) alone. LVEF served as a surrogate measure of effect in all studies. The follow-up period lasted from one to six weeks. Survival curves and mortality data were only provided by four studies and, thus, not included in the meta-analysis. Data on left ventricular end-diastolic volume and left ventricular end-systolic volume were not reported in seven groups and thus not considered. None of the studies included reported safety end points such as "Major Cardiovascular Adverse Events" (MACE). In 22 of the 34 included groups, immunodeficient mice were used, yet tumor - more precisely teratoma formation in animals receiving murine PSCs were reported in two of these groups only [21, 22].

\section{Meta-analysis}

The random effects meta-analysis model revealed that cardiac stem cell therapies, including both adult and pluripotent stem cells, significantly improve left ventricular systolic function after ischemic damage in mice: cell injection leads to an increase in LVEF of $8.59 \%$ +/- 2.36 (95\% CI 3.7 - 13.8; p=.012, Fig. 2) in treated animals in comparison to control animals receiving suspending agent only. This improvement is referred to as the "overall" effect in the following section.

The model was chosen after performing the test for homogeneity ( $\mathrm{p}=.083$, Fig. 3) and calculating the between-study variance $\left(\tau^{2}=.01\right.$, Fig. 3$)$, as well as inconsistency $\left(\mathrm{I}^{2}=33.39 \%\right.$, 
\begin{tabular}{cl|l} 
Cellular Physiology & Cell Physiol Biochem 2017;42:254-268 \\
and Biochemistry & $\begin{array}{c}\text { DOI: 10.1159/000477324 } \\
\text { Published online: May 19, } 2017\end{array}$ & $\begin{array}{l}\text { O 2017 The Author(s). Published by S. Karger AG, Basel } \\
\text { www.karger.com/cpb }\end{array}$ \\
\cline { 2 - 3 } &
\end{tabular}

Lang et al.: Meta-Analysis: Cardiac Stem Cell Therapies in Mice

\begin{tabular}{|c|c|c|c|c|c|c|c|c|c|c|c|}
\hline Author & nlc & $\mathrm{nt}$ & Cell type & Donor & Host & $\overline{\text { Sex }}$ & $\begin{array}{l}\text { Number of } \\
\text { Cells }\end{array}$ & $\begin{array}{l}\text { Number of } \\
\text { Injections }\end{array}$ & Volume & $\begin{array}{l}\text { Suspending } \\
\text { Agent }\end{array}$ & $\begin{array}{l}\text { Follow- } \\
\text { up } \\
\text { (weeks) }\end{array}$ \\
\hline Arai et al. [57] & 5 & 7 & ESC & $129 S v / J$ & $129 S v / J$ & $\mathrm{f}$ & 250000 & 1 & 25 & medium & 4 \\
\hline Au et al. [58] & 5 & 5 & ESC & $129 \mathrm{~Sv} / \mathrm{J}$ & CD-1 (ICR) & $\mathrm{n} / \mathrm{a}$ & 300000 & 1 & 10 & medium & 1 \\
\hline \multirow[t]{2}{*}{ Bai et al. [59] } & 7 & 7 & fASC & human & SCID & $\mathrm{m}$ & 500000 & 2 & 30 & PBS & 4 \\
\hline & & 7 & $\mathrm{ASC}$ & human & SCID & $\mathrm{m}$ & 500000 & 2 & 30 & PBS & 4 \\
\hline denHaan et al. [60] & 12 & 11 & CMPC & human & NOD/SCID & $\mathrm{m}$ & 200000 & 5 & 20 & medium & 2 \\
\hline Drey et al. [61] & 5 & 5 & MSC & C57BL/6 & $\mathrm{C} 57 \mathrm{BL} / 6$ & $\mathrm{~m}$ & 100000 & 1 & 10 & PBS & 4 \\
\hline Grauss et al. [62] & 14 & 12 & MSC & human & NOD/SCID & $\mathrm{m}$ & 200000 & 5 & 20 & medium & 2 \\
\hline Grauss et al. [63] & 12 & 10 & MSC & human & NOD/SCID & $\mathrm{m}$ & 200000 & 5 & 20 & medium & 2 \\
\hline \multirow[t]{2}{*}{ Hendry et al. [21] } & 6 & 23 & ESC & $129 / \mathrm{SV}$ & Scid/beige & $\mathrm{f}$ & 250000 & $\mathrm{n} / \mathrm{a}$ & 25 & saline & 1 \\
\hline & & 17 & $\mathrm{EF}$ & $\mathrm{n} / \mathrm{a}$ & Scid/beige & $\mathrm{f}$ & 250000 & $\mathrm{n} / \mathrm{a}$ & 25 & saline & 1 \\
\hline Huber et al. [64] & 7 & 8 & ESC-EC & human & FVB & $\mathrm{n} / \mathrm{a}$ & 2000000 & 2 & 30 & PBS & 4 \\
\hline \multirow[t]{3}{*}{ Kim et al.[22] } & 9 & 9 & AMC & human & Scid/beige & $\mathrm{m}$ & 250000 & $\mathrm{n} / \mathrm{a}$ & 20 & matrigel & 4 \\
\hline & & 8 & AMC kit & human & Scid/beige & $\mathrm{m}$ & 250000 & $\mathrm{n} / \mathrm{a}$ & 20 & matrigel & 4 \\
\hline & & 9 & iPSC & human & Scid/beige & $\mathrm{m}$ & 250000 & $\mathrm{n} / \mathrm{a}$ & 20 & matrigel & 4 \\
\hline Kofidis et al. [65] & 5 & 5 & ESC-CM & human & Scid/beige & $\mathrm{f}$ & 1000000 & $\mathrm{n} / \mathrm{a}$ & 25 & medium & 3 \\
\hline \multirow[t]{2}{*}{ Liao et al. [66] } & 8 & 8 & ESC-CM & $129 / \mathrm{Sv}$ & CD-1 (ICR) & $\mathrm{f}$ & 300000 & 1 & 10 & medium & 3 \\
\hline & & 8 & ESC & $129 / \mathrm{Sv}$ & CD-1 (ICR) & $\mathrm{f}$ & 300000 & 1 & 10 & medium & 3 \\
\hline Liu et al.[67] & 10 & 37 & $\mathrm{CPC}$ & human & Scid/beige & $\mathrm{f}$ & 1000000 & 3 & 20 & PBS & 4 \\
\hline \multirow[t]{2}{*}{ Mauritz et al. [10] } & 13 & 14 & iPSC Flk- & mouse & Scid/beige & $\mathrm{n} / \mathrm{a}$ & 500000 & 1 & 15 & PBS & 2 \\
\hline & & 11 & iPSC Flk+ & mouse & Scid/beige & $\mathrm{n} / \mathrm{a}$ & 500000 & 1 & 15 & PBS & 2 \\
\hline Ong et al. [68] & 8 & 8 & iPSC-CM & human & NOD/SCID & $\mathrm{f}$ & 2000000 & $\mathrm{n} / \mathrm{a}$ & 20 & $\mathrm{n} / \mathrm{a}$ & 5 \\
\hline \multirow{3}{*}{ Paulis et al. [69] } & 8 & 5 & $\mathrm{eCM}$ & $\mathrm{CD}-1$ & CD-1 & $\mathrm{m}$ & $1-2 \times 10^{5}$ & $\mathrm{n} / \mathrm{a}$ & 5 & medium & 2 \\
\hline & & 7 & SM & CD-1 & CD-1 & $\mathrm{m}$ & $1-2 \times 10^{5}$ & $\mathrm{n} / \mathrm{a}$ & 5 & medium & 2 \\
\hline & & 7 & MSC & CD-1 & CD-1 & $\mathrm{m}$ & $1-2 \times 10^{5}$ & $\mathrm{n} / \mathrm{a}$ & 5 & medium & 2 \\
\hline Rojas et al. [70] & 10 & 9 & iPSC & mouse & Scid/beige & $\mathrm{n} / \mathrm{a}$ & 1000000 & $\mathrm{n} / \mathrm{a}$ & 15 & fibrinogen & 2 \\
\hline \multirow[t]{2}{*}{ Smits et al. [71] } & 9 & 11 & CMPC & human & NOD/SCID & $\mathrm{m}$ & 500000 & 2 & 10 & PBS & 4 \\
\hline & & 10 & CMPC-CM & human & NOD/SCID & $\mathrm{m}$ & 500000 & 2 & 10 & PBS & 4 \\
\hline \multirow[t]{3}{*}{ vanLaake et al. [72] } & 13 & 12 & ESC-CM & human & NOD/SCID & $\mathrm{m}$ & 3000000 & 3 & 15 & medium & 4 \\
\hline & & 14 & ESC-CM & human & NOD/SCID & $\mathrm{m}$ & 1000000 & 1 & 15 & medium & 4 \\
\hline & & 12 & ESC-non CM & human & NOD/SCID & $\mathrm{m}$ & 1000000 & 1 & 15 & medium & 4 \\
\hline Wang et al. [73] & 6 & 6 & MSC & human & SCID & f & 500000 & $\mathrm{n} / \mathrm{a}$ & $25-30$ & medium & 4 \\
\hline \multirow[t]{3}{*}{ Winter et al.[74] } & 17 & 20 & EPDC & human & NOD/SCID & $\mathrm{n} / \mathrm{a}$ & 400000 & $\mathrm{n} / \mathrm{a}$ & $\mathrm{n} / \mathrm{a}$ & medium & 6 \\
\hline & & 13 & CMPC & human & NOD/SCID & $\mathrm{n} / \mathrm{a}$ & 400000 & $\mathrm{n} / \mathrm{a}$ & $\mathrm{n} / \mathrm{a}$ & medium & 6 \\
\hline & & 14 & $\mathrm{CMPC}+\mathrm{EPDC}$ & human & NOD/SCID & $\mathrm{n} / \mathrm{a}$ & 400000 & $\mathrm{n} / \mathrm{a}$ & $\mathrm{n} / \mathrm{a}$ & medium & 6 \\
\hline
\end{tabular}

Table 1. Characteristics of included studies. ESC, embryonic stem cell; iPSC, induced pluripotent stem cell; fASC, fresh adipose tissue-derived stem cell; CMPC, cardiomyocyte progenitor cell; MSC, mesenchymal stem cell; EF, embryonic fibroblast; ESC-CM, ESC-derived cardiomyocytes; iPSC, induced pluripotent stem cell; eCM, embryonic cardiomyocyte; SM, skeletal myoblast; CMPC-CM, CMPC-derived cardiomyocytes; EPDC, epicardium derived cell; PBS, phosphate buffered saline; F, female; M, male; n/a, not applicable; 129Sv/J, CD-1, C57/BL6, 129/Sv: mouse strains; SCID, NOD/SCID SCID-beige: immune-deficient murine strains; $\mathrm{n}$. number of animals $\left(\mathrm{n}_{\mathrm{c}^{\prime}}\right.$ control; $\mathrm{n}_{\mathrm{t}^{\prime}}$ treated)

Fig. 2. Results of the meta-analysis visualized in a forest plot. Forest plot based on random effects model (maximum likelihood estimator; weights calculated by weighted least square algorithm) and difference in LVEF (reported in \%) and the corresponding $95 \%$ confidence intervals.

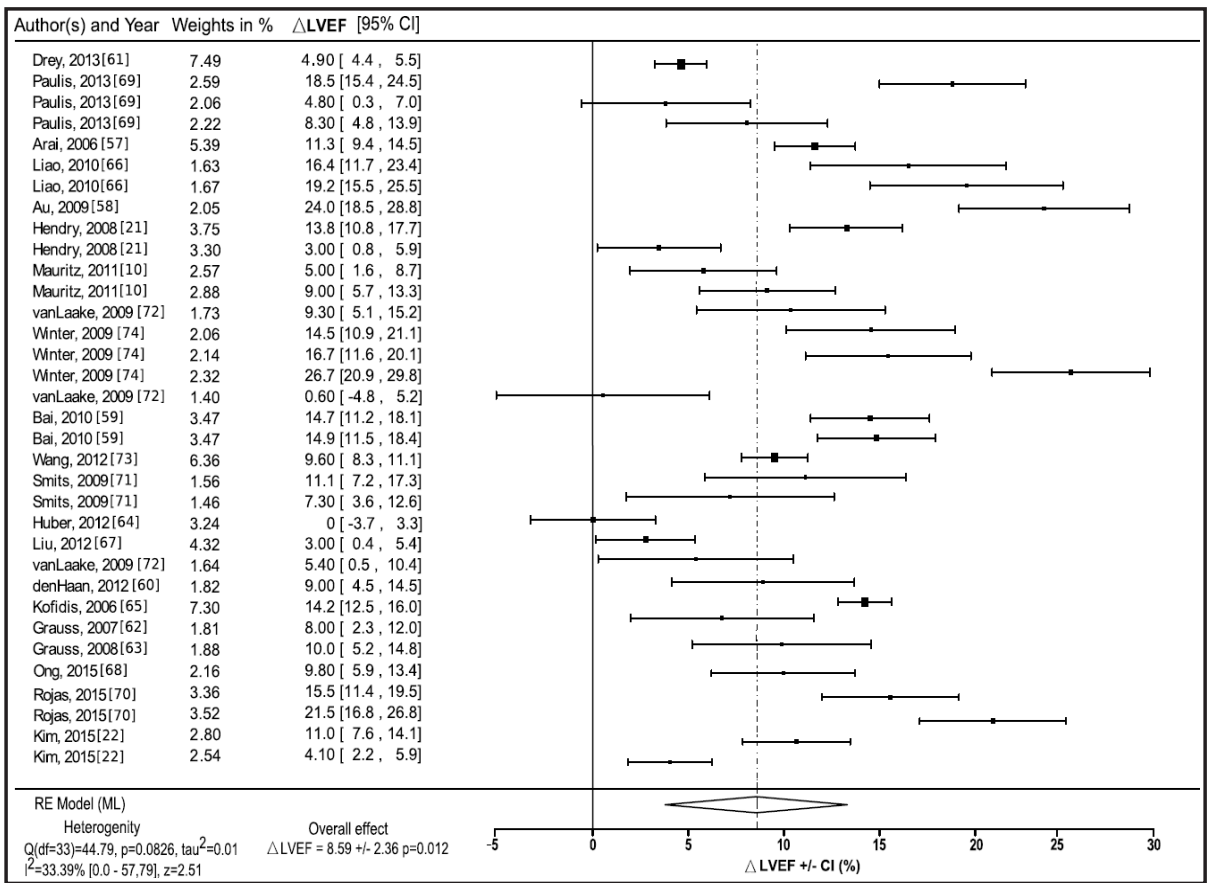


Fig. 3. Characterization of the random effect model estimator. Between study variance $\tau^{2}$ and inconsistency $\mathrm{I}^{2}$ to assess the heterogeneity of studies regarding Hunter-Schmidt estimator (HS), DerSimonianLaird estimator (DL), SidikJonkman estimator (SJ), the maximum-likelihood estimator (ML), restricted maximumlikelihood estimator (REML) and empirical Bayes estimator

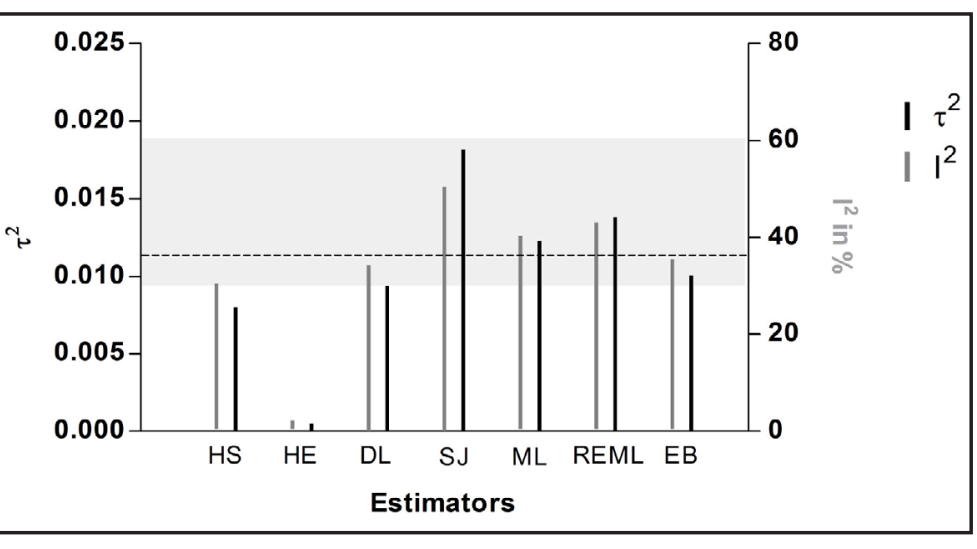
(EB). $\tau^{2}$ is considered to be significant ( $\mathrm{p}=.01$ ) according to Salenti et al. [16]. $\mathrm{I}^{2}$ evaluation according to Higgins et al. [56]: low (<25\%), moderate $(25 \%-75 \%)$ and high $(>75 \%)$ inconsistency.

Fig. 4. Funnel plots assessing for publication bias. The funnel plots show observed study outcomes (black dots) and predicted missing studies (white dots) on the $\mathrm{x}$-axis plotted against their corresponding standard errors on the y-axis. A vertical line indicates the estimate based on $\mathrm{A}$, the random effects, or $B$ the fixed-effects model. A pseudo confidence interval region is drawn around this value with bounds equal to $\pm 1.96 *$ SE, where SE is the mean standard error value from the y-axis.

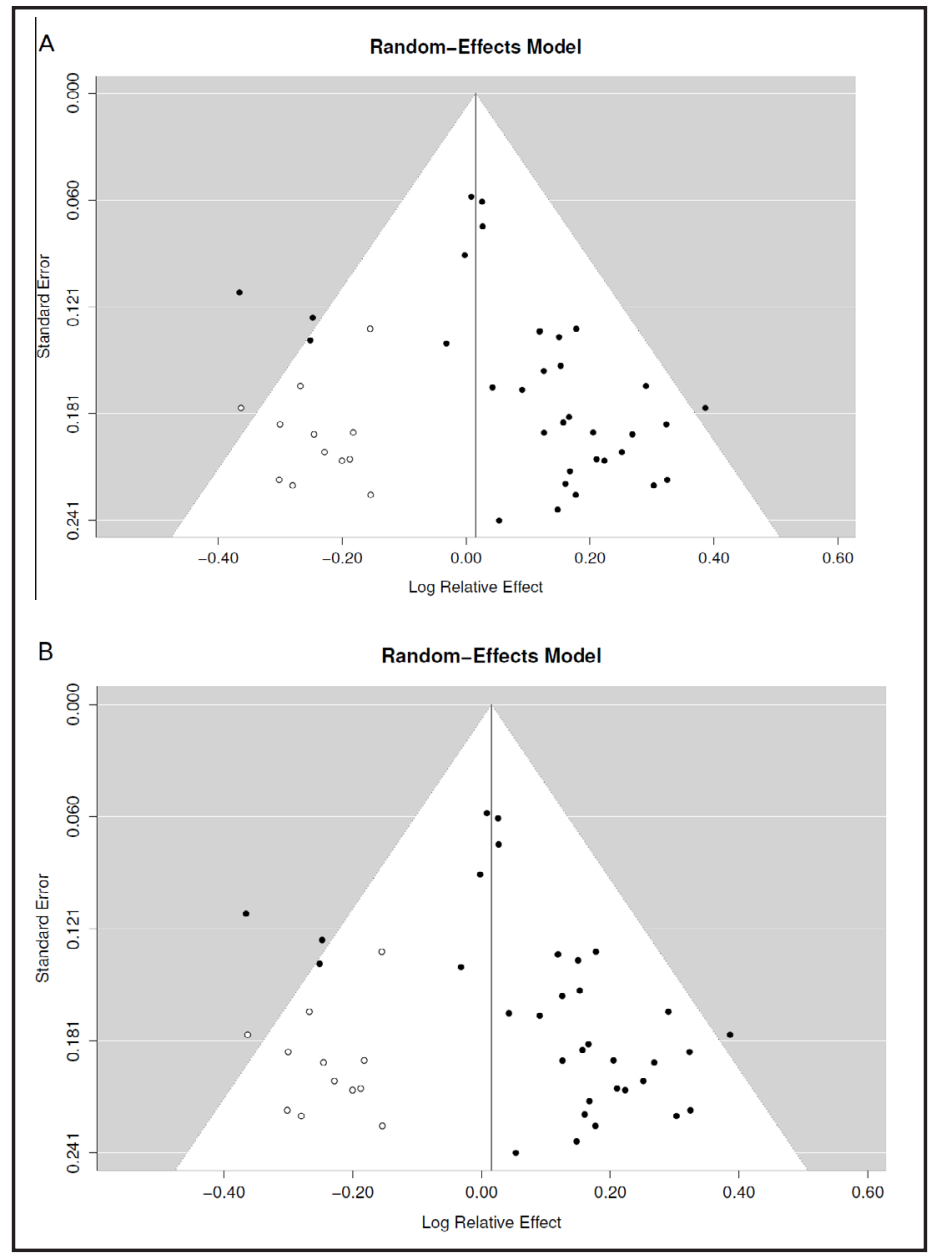

Fig. 3). Furthermore, no publication bias could be detected (Fig. 4): funnel plots demonstrated symmetric behaviour and Egger's regression test for symmetry was not significant ( $p=.4$ ).

\section{Subgroup analysis}

In addition to assessing the overall efficacy of cardiac cell therapies in mice, we also performed a subgroup analysis using meta-regression to explore the impact of different cell types, cell origin, cell number, recipient gender, follow-up time and number of injections on LVEF (Table 2).

\section{KARGER}


Fig. 5. Subgroup analysis to identify significant moderators. Meta-regression analysis of subgroups revealed factors that significantly influence the magnitude of the functional improvement afforded by cell therapies - using LVEF improvement as a surrogate marker for efficacy. A Cell type has no significant effect on the magnitude of LVEF improvement $(\mathrm{p}<.48)$. B Cell origin has an impact on efficacy: allogeneic cells are most effective (12.9\%; $p=.046)$. C Less than 500,000 cells are more effective than higher numbers $(\mathrm{p}=.013)$. D The highest increase in LVEF can be measured up to 3 weeks post-transplantation ( $\mathrm{p}=.004)$. E Females benefit more from cardiac stem cell therapies than male mice $(p=.003)$. F The overall effect of all investigated studies. *Marked as significant according to regression coefficient of the respective fixed-effects model.

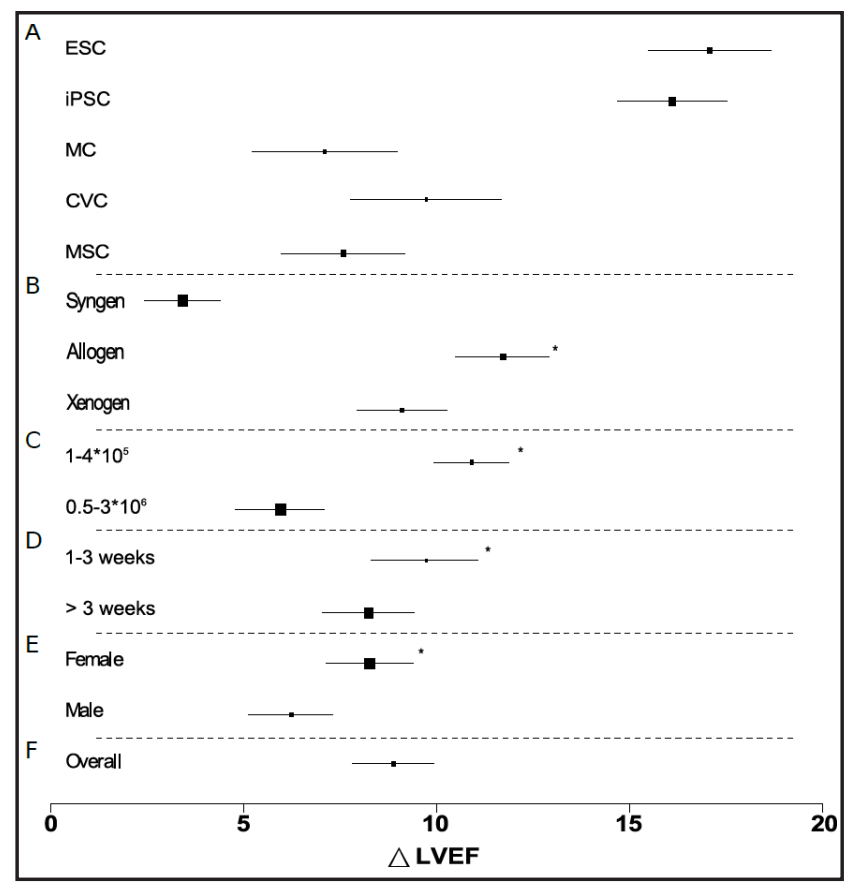

Table 2. Summary of meta-regression analyses for different factors and their respective impact on the effect $(\triangle \mathrm{LVEF})$ of cardiac stem cell therapies. ESC, embryonic stem cells; iPSC, induced pluripotent stem cell; MC, mesodermal cells; CVC, cardiovascular cells and progenitors; MSC, mesenchymal stem cells. *Marked as significant according to regression coefficient of the respective fixed-effects model

\begin{tabular}{|c|c|c|c|}
\hline Variable & Subgroups & $\begin{array}{l}\text { Difference in } \\
\text { LVEF (\%) }\end{array}$ & $\overline{p \text {-value }}$ \\
\hline \multirow{6}{*}{ Cell types } & Overall & 8.59 & \multirow{6}{*}{0.483} \\
\hline & ESC & $\begin{array}{l}17.1 \\
15.9\end{array}$ & \\
\hline & MC & 7.2 & \\
\hline & $\mathrm{CVC}$ & 9.9 & \\
\hline & MSC & 7.5 & \\
\hline & Syngen & 3.45 & \\
\hline \multirow[t]{2}{*}{ Cell origin } & Allogen & 11.89 & \multirow[t]{2}{*}{$0.046^{*}$} \\
\hline & Xenogen & 9.2 & \\
\hline \multirow[t]{3}{*}{ Gender } & Female & 8.7 & \multirow{3}{*}{$0.003^{*}$} \\
\hline & Male & 6.5 & \\
\hline & $1-4 * 10^{5}$ & 10.78 & \\
\hline \multirow[t]{2}{*}{ Cell amount } & $0.5-3 * 10^{6}$ & 6.3 & \multirow[t]{2}{*}{$0.013^{*}$} \\
\hline & 1-3 weeks & 10.6 & \\
\hline \multirow[t]{2}{*}{ Follow up } & $>3$ weeks & 5.3 & \multirow[t]{2}{*}{$0.004^{*}$} \\
\hline & $1-2$ & 8.7 & \\
\hline Injections & $3-5$ & 5.5 & 0.14 \\
\hline
\end{tabular}

Which cell type is most effective? Applied cells were divided into four subgroups: ESC (embryonic stem cells), iPSC (induced pluripotent stem cells), MSC (mesenchymal stem cells), CVC (cardiovascular cells) and MC (adult mesodermal cells). These led to an improvement in LVEF of $17.1 \%$ (ESC), 15.9\% (iPSC), 9.9\% (CVC), 7.5\% (MSC) and 7.2\% (MC) compared to the respective control group (Fig. $5 \mathrm{~A}$ ). However, there were no significant differences in efficacy between cell type ( $\mathrm{p}=.48)$.

Impact of cell origin: Syngeneic, allogeneic and xenogeneic cells had significantly different impacts on LVEF improvement (3.45\%, 11.89\%, 9.2\%; $\mathrm{p}=.046)$, favoring transplantation of allogeneic cells (Fig. 5 B). 
Number of injected cells: The injection of less than 500,000 cells resulted in significantly higher LVEF improvements than the injection of 500,000 cells or more (LVEF improvement of $10.8 \%$ vs. $6.3 \%$; p=.01; Fig. 5 C).

Follow up time: LVEF improvements measured 1 to 3 weeks following cell injection were significantly higher compared with longer follow-up ( $>3$ weeks); (LVEF improvement of $10.6 \%$ vs. $5.3 \%$; p=.004; Fig. 5 D).

Female vs. Male: Female mice benefited significantly more from cardiac cell therapies than their male counterparts (LVEF improvement of 8.7\% vs. 6.5\%; p=.003; Fig. 5 E).

Impact of other factors: No significant differences were observed between groups for the number of injections (Table 2).

\section{Power-Analysis}

Based on our results, we used the $\triangle \mathrm{LVEF}$ improvement as a surrogate measure of effect to perform a post hoc power analysis. Using our parameters $(n=583, \Delta \mathrm{LVEF}=8.59 \%, \alpha=.05$, one-tailed $t$ test) we obtained a power of .81 .

\section{Discussion}

This meta-analysis of 22 studies, including a total of 583 animals, was performed to assess the efficacy of cardiac cell therapies in mitigating post-MI contractile dysfunction in mice. Our analysis shows that intra-myocardial cell injection increases LVEF by $8.59 \%$ as measured by MRI. Moreover, meta-regression analyses performed to identify moderators responsible for the LVEF improvement indicate that:

i) Significantly greater increases in LVEF are associated with:

a. Application of allogenic cells (compared to syngeneic and xenogeneic);

b. Female animal recipients;

c. Less than 500,000 injected cells;

d. Follow-up times up to three weeks post-cell application.

ii) Cell type and number of cell injections have no significant impact on the magnitude of LVEF improvement.

These findings are discussed in detail, below.

Relevance of the mouse model for efficacy testing of cardiac stem cell therapies

Studies using rodents have contributed significantly to recent advances in cardiovascular biology and provided proof-of-concept for the development of novel therapeutics [23]. However, the ability of small rodents - particularly the mouse model - to predict the results of human stem cell-based myocardial regenerative trials has been vigorously challenged [11]. This assumption is based on the premise that the anatomical and physiological differences between mice and humans are sufficient to lead to variant results between preclinical models and clinical trials. However, objective data corroborating this assumption are lacking. The most frequently quoted differences between human and murine hearts relate to divergences in calcium handling properties [24], ventricular expression of motor proteins [25], organ size and beating frequency, and coronary architecture [26]. That these fundamental differences can be clinically germane is exemplified by the finding that mice with heart failure benefit from phospholamban (PLN) ablation, whereas humans lacking PLN develop lethal dilated cardiomyopathy [24].

Yet, it would be wrong to conclude from this observation that mice are inappropriate models to predict results of clinical stem cell therapy trials. Rather, such differences between mice and men highlight that an understanding of the mode of action of therapies is indispensable for the development of novel therapies using rodent models. As a corollary, the appropriateness of the mouse model to predict the clinical results of cardiac stem cell therapies depends fundamentally on the alleged targeted biological mechanism. Aiming 


\section{Cellular Physiology Cell Physiol Biochem 2017;42:254-268

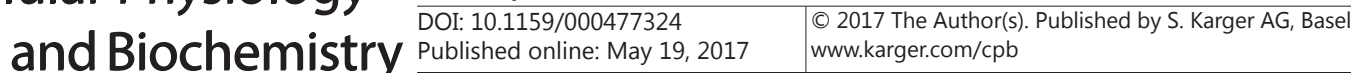

Lang et al.: Meta-Analysis: Cardiac Stem Cell Therapies in Mice

at functional replacement of beating cardiomyocytes alone, fundamental interspecies physiological and anatomical differences might limit the validity of rodent results to predict clinical outcome [27]. However, when highly conserved biological pathways and processes are targeted, we believe the mouse to be a valid model for the prediction of clinical results of regenerative therapy. Beneficial effects of cardiac cell therapies have been mainly attributed to modulation of apoptosis [28, 29], inflammation and angiogenesis [30-33]. Intriguingly, these mechanisms are highly conserved biological pathways in mammals [34-36]. This corroborates our hypothesis that the mouse is a valid model to predict the magnitude of LVEF improvement in clinical trials of cell therapies for the treatment of ischemic myocardium. The mouse model is cheap, has a short reproductive cycle and can be easily genetically modified [26], providing an excellent tool for studies of mode of action, proof-of-concept studies and biological safety testing [37].

Our meta-analysis reveals that application of cardiac cell therapies for treatment of ischaemic myocardium in mice results in an increase in LVEF by $~ 8.6 \%$. This value is in striking agreement with results from the largest meta-analysis undertaken in large animal models (including 1,415 animals) which reported an increase in LVEF by $8.3 \%$ following stem cell application [38].

At the point of having identified an attractive cell type for cardiac repair, the ultimate application of the respective cell preparation has to be made in animal models faithfully recapitulating the clinical setting. In this context, large animals with similar anatomical and physiological properties, like pigs, will play a predominant role in translational research. This applies particularly to points in the final steps from bench to bedside, such as the exact clinical scenario treated, route of application, the time point of cell administration, the choice of device for cell injection, safety of these tools and the biodistribution of cells in a model with similar anatomical proportions.

In this context, large animal models with anatomical and physiological properties similar to patients, enable the use of clinical relevant endpoints such as mortality, major adverse cardiovascular events (MACE), cardiac dimensions and hemodynamics.

Impact of cell source (allogeneic)

To the best of our knowledge, neither preclinical nor clinical studies have compared the efficacy of allogeneic versus autologous stem cells as regenerative therapy post-MI. Hare et al. [39] showed that both autologous and allogeneic MSCs are safe in the treatment of ischemic cardiomyopathy in patients. Furthermore, data from a meta-analysis in large animal models suggest that allogeneic MSCs are as efficacious as autologous MSCs in improving myocardial pump function [38].

Our meta-analysis shows that use of allogeneic cells leads to significantly greater LVEF improvement than syngeneic cells. Even though syngeneic cell transplantation into inbred mice strains is not directly comparable to autologous cell transplantation, our results support the postulate that allogeneic cell application may provide an attractive alternative to autologous cell-based therapies. The allogeneic approach may allow for 'off the shelf' stem cell therapies and the use of highly potent cell preparations from young healthy donors.

\section{Gender}

To our knowledge, this meta-analysis is the second one to provide evidence that female sex is associated with greater responsivity to cardiac cell therapies. Our results are in agreement with a meta-analysis investigating the influence of patient characteristics on study results by meta-regression. In the latter study, male individuals benefitted less than females from intracoronary infused bone marrow stem cells for the treatment of acute myocardial infarction [40]. Interestingly, the relevance of gender specific approaches in the field of cardiovascular medicine has increased over the last few years. Both clinical and preclinical studies indicate that female sex favourably influences the remodelling and adaptive response to myocardial infarction [41]. Furthermore, a greater resistance of female myocardium to ischemia/reperfusion injury has been demonstrated in several animal 
models [41]. Increased angiogenesis, which might be mediated by estradiol-dependent pathways, has been suggested as a potential mechanism underlying these effects $[42,43]$. Further evidence is required to elucidate the impact of sex on responsiveness to cardiac cell therapy.

\section{Cell number}

Different strategies have been proposed to improve the very low engraftment rates following intramyocardial cell injection [44-46], a reasonable consideration when targeting functional replacement of deceased cardiomyocytes. With a primary goal of functional tissue replacement it seems logical that the effects of cell-based therapies will depend on the number of cells administered [47]. However, other modes of action underlying the beneficial effect of cardiac cell therapies beyond direct regeneration, such as paracrine effects, are currently assumed to predominate [32]. Notwithstanding this, little attention has been paid to date to dose-response relationships in the field of cardiac cell therapies. Meta-analyses of clinical studies have reported inconsistent results concerning the effect of administered cell number on LVEF improvement [5, 48-51].

Intriguingly, in our study meta-regression analysis revealed that - in mice - injection of cell numbers lower than 500,000 lead to significantly higher LVEF improvements. This suggests that paracrine mechanisms, as opposed to simple functional tissue replacement, are a key contributor to the observed improvement in LVEF.

\section{Follow up}

Both clinical and preclinical studies have reported that the positive effects of cardiac cell therapies on LVEF fade away during long-term follow up [13, 52]. Peak LVEF improvement has been assessed after six months in the clinical setting [52] and at up to one to two weeks in large animal models [13]. This is in line with the results from our meta-regression analysis showing that LVEF improvement is significantly higher within the first 3 weeks after cell application compared to longer follow-up times.

\section{Number of cell injections}

The number of cell injections did not have a significant effect on LVEF improvement. This correlation has not been directly investigated yet - either in clinical or preclinical studies. It has been speculated that intramyocardial injections disrupt tissue architecture and lead to inhomogeneous cell distribution within the infarcted area [47]. In order to provide robust data on both the optimal number of cells and individual injections, preclinical and clinical studies systematically addressing these questions for a specific cell type are necessary.

"Regenerative potential" of ESCs

The preclinical data obtained from our meta-analysis indicates that ESCs have a high potential to improve cardiac function following myocardial infarction (Fig. 5 A). Early reports have suggested "guided" differentiation into cardiomyocytes of ESCs transplanted into healthy and ischemic myocardium [53]. This hypothesis has been refuted by Nussbaum et al. who showed that neither healthy nor ischemic myocardium guides differentiation of ESCs into cardiomyocytes [54]. In fact, undifferentiated ESCs form teratomas in both syngeneic and allogeneic recipients [54], thereby strictly excluding them from therapeutic approaches.

While efficacy has been demonstrated for ESCs, their incapability to form cardiomyocytes in vivo suggests that modes of action beyond direct regeneration underlie the reported beneficial effect of intramyocardially transplanted ESCs.

Burt et al. showed that mitotically inactivated ESCs improve cardiac function although do not survive long-term, thus circumventing adverse effects such as tumour formation [55]. The proposed mode of action was transient function as an in vivo feeder layer that nurses damaged myocardium.

While further investigation is necessary to understand the mechanisms underlying improved cardiac function other than functional tissue replacement, our data demonstrate 
that the mouse is a valid model to address the efficacy of cell-based therapy post myocardial infarction.

\section{Conclusion}

To our knowledge, this is the first systematic review and meta-analysis to assess the effect of cell therapies in murine models of acute myocardial infarction.

In contrast to previous meta-analyses addressing large animals [13, 38] and humans [49], pluripotent stem cells and their derivatives have been included.

Furthermore, the magnitude of LVEF improvement is strikingly similar to results obtained from the most extensive meta-analysis of large animal models $[13,38]$. This emphasizes the high relevance and reliability of the mouse model for evaluating the effect of new cell types for cardiac repair.

\section{Funding}

This work has been funded by the Federal Ministry of Education and Research Germany (FKZ 0312138A, FKZ 316159 and FKZ 02NUK043C) and the State MecklenburgWestern Pomerania with EU Structural Funds (ESF/IV-WM-B34-0030/10 and ESF/IVBM-B35-0010/12), by the BMBF (VIP+-Project 03VP00241), DFG (DA 1296-1), the German Heart Research Foundation (F/34/15) and by the FORUN Program of Rostock University Medical Centre (889001) and the EU funded CaSyM project (grant agreement \#305033).

\section{Disclosure Statement}

The authors report no relationships that could be constructed as a conflict of interest.

\section{References}

1 Nichols M TN, Luengo-Fernandez R, Leal J, Gray A, Scarborough P, Rayner M: European Cardiovascular Disease Statistics 2012. European Heart Network, Brussels, European Society of Cardiology, Sophia Antipolis 2012;

2 Strauer BE, Brehm M, Zeus T, Gattermann N, Hernandez A, Sorg RV, Kogler G, Wernet P: [Intracoronary, human autologous stem cell transplantation for myocardial regeneration following myocardial infarction]. Dtsch Med Wochenschr 2001;126:932-938.

-3 Stamm C, Westphal B, Kleine HD, Petzsch M, Kittner C, Klinge H, Schumichen C, Nienaber CA, Freund M, Steinhoff G: Autologous bone-marrow stem-cell transplantation for myocardial regeneration. Lancet 2003;361:45-46.

4 Menasche P, Vanneaux V, Fabreguettes JR, Bel A, Tosca L, Garcia S, Bellamy V, Farouz Y, Pouly J, Damour O, Perier MC, Desnos M, Hagege A, Agbulut O, Bruneval P, Tachdjian G, Trouvin JH, Larghero J: Towards a clinical use of human embryonic stem cell-derived cardiac progenitors: a translational experience. Eur Heart J 2014;10.1093/eurheartj/ehu192

-5 Abdel-Latif A, Bolli R, Tleyjeh IM, Montori VM, Perin EC, Hornung CA, Zuba-Surma EK, Al-Mallah M, Dawn B: Adult bone marrow-derived cells for cardiac repair: a systematic review and meta-analysis. Arch Intern Med 2007;167:989-997.

6 Donndorf P, Kaminski A, Tiedemann G, Kundt G, Steinhoff G: Validating intramyocardial bone marrow stem cell therapy in combination with coronary artery bypass grafting, the PERFECT Phase III randomized multicenter trial: study protocol for a randomized controlled trial. Trials 2012;13:99.

Segers VF, Lee RT: Stem-cell therapy for cardiac disease. Nature 2008;451:937-942.

David R, Franz WM: From pluripotency to distinct cardiomyocyte subtypes. Physiology (Bethesda)

2012;27:119-129. 


\section{Cellular Physiology Cell Physiol Biochem 2017;42:254-268 \begin{tabular}{l|l} 
DOI: 10.1159/000477324 & and Biochemistry 2017 The Author(s). Published by S. Karger AG, Basel \\
wwww.karger.com/cpb
\end{tabular}}

Lang et al.: Meta-Analysis: Cardiac Stem Cell Therapies in Mice

-9 Jung JJ, Husse B, Rimmbach C, Krebs S, Stieber J, Steinhoff G, Dendorfer A, Franz WM, David R: Programming and isolation of highly pure physiologically and pharmacologically functional sinus-nodal bodies from pluripotent stem cells. Stem Cell Reports 2014;2:592-605.

10 Mauritz C, Martens A, Rojas SV, Schnick T, Rathert C, Schecker N, Menke S, Glage S, Zweigerdt R, Haverich A, Martin U, Kutschka I: Induced pluripotent stem cell (iPSC)-derived Flk-1 progenitor cells engraft, differentiate, and improve heart function in a mouse model of acute myocardial infarction. Eur Heart J 2011;32:2634-2641.

11 Harding J, Roberts RM, Mirochnitchenko O: Large animal models for stem cell therapy. Stem Cell Res Ther 2013;4:23.

12 Cibelli J, Emborg ME, Prockop DJ, Roberts M, Schatten G, Rao M, Harding J, Mirochnitchenko O: Strategies for improving animal models for regenerative medicine. Cell Stem Cell 2013;12:271-274.

$\checkmark 13$ van der Spoel TI, Jansen of Lorkeers SJ, Agostoni P, van Belle E, Gyongyosi M, Sluijter JP, Cramer MJ, Doevendans PA, Chamuleau SA: Human relevance of pre-clinical studies in stem cell therapy: systematic review and meta-analysis of large animal models of ischaemic heart disease. Cardiovasc Res 2011;91:649658.

14 Viechtbauer W: Bias and efficiency of meta-analytic variance estimators in the random-effects model. Journal of Educational and Behavioral Statistics 2005;30:261-293.

15 Dodge Y, International Statistical Institute.: The Oxford dictionary of statistical terms, [6th, Oxford University Press, Oxford, 2003.

16 Salanti G, Del Giovane C, Chaimani A, Caldwell DM, Higgins JP: Evaluating the quality of evidence from a network meta-analysis. PLoS One 2014;9:e99682.

17 Duval S, Tweedie R: A nonparametric "trim and fill" method of accounting for publication bias in metaanalysis. J Am Stat Assoc 2000;95:89-98.

-18 Egger M, Davey Smith G, Schneider M, Minder C: Bias in meta-analysis detected by a simple, graphical test. BMJ 1997;315:629-634.

19 Viechtbauer W: Conducting Meta-Analyses in R with the metafor Package. J Stat Software 2010;36:1-48.

20 Champely S: Basic Functions for Power Analysis. 2015.

21 Hendry SL, 2nd, van der Bogt KE, Sheikh AY, Arai T, Dylla SJ, Drukker M, McConnell MV, Kutschka I, Hoyt G, Cao F, Weissman IL, Connolly AJ, Pelletier MP, Wu JC, Robbins RC, Yang PC: Multimodal evaluation of in vivo magnetic resonance imaging of myocardial restoration by mouse embryonic stem cells. J Thorac Cardiovasc Surg 2008;136:1028-1037 e1021.

22 Kim PJ, Mahmoudi M, Ge X, Matsuura Y, Toma I, Metzler S, Kooreman NG, Ramunas J, Holbrook C, McConnell MV, Blau H, Harnish P, Rulifson E, Yang PC: Direct evaluation of myocardial viability and stem cell engraftment demonstrates salvage of the injured myocardium. Circ Res 2015;116:e40-50.

23 Chong JJ, Murry CE: Cardiac regeneration using pluripotent stem cells--progression to large animal models. Stem Cell Res 2014;13:654-665.

-24 Haghighi K, Kolokathis F, Pater L, Lynch RA, Asahi M, Gramolini AO, Fan GC, Tsiapras D, Hahn HS, Adamopoulos S, Liggett SB, Dorn GW, 2nd, MacLennan DH, Kremastinos DT, Kranias EG: Human phospholamban null results in lethal dilated cardiomyopathy revealing a critical difference between mouse and human. J Clin Invest 2003;111:869-876.

-25 James J, Zhang Y, Wright K, Witt S, Glascock E, Osinska H, Klevitsky R, Martin L, Yager K, Sanbe A, Robbins J: Transgenic rabbits expressing mutant essential light chain do not develop hypertrophic cardiomyopathy. J Mol Cell Cardiol 2002;34:873-882.

26 Zaragoza C, Gomez-Guerrero C, Martin-Ventura JL, Blanco-Colio L, Lavin B, Mallavia B, Tarin C, Mas S, Ortiz A, Egido J: Animal models of cardiovascular diseases. J Biomed Biotechnol 2011;2011:497841.

27 Chong JJ, Yang X, Don CW, Minami E, Liu YW, Weyers JJ, Mahoney WM, Van Biber B, Cook SM, Palpant NJ, Gantz JA, Fugate JA, Muskheli V, Gough GM, Vogel KW, Astley CA, Hotchkiss CE, Baldessari A, Pabon L, Reinecke H, Gill EA, Nelson V, Kiem HP, Laflamme MA, Murry CE: Human embryonic-stem-cell-derived cardiomyocytes regenerate non-human primate hearts. Nature 2014;510:273-277.

-28 Zhang J, He Z, Xiao W, Na Q Wu T, Su K, Cui X: Overexpression of BAG3 Attenuates Hypoxia-Induced Cardiomyocyte Apoptosis by Inducing Autophagy. Cell Physiol Biochem 2016;39:491-500.

29 Ludwig M, Tolk A, Skorska A, Maschmeier C, Gaebel R, Lux CA, Steinhoff G, David R: Exploiting AT2R to Improve CD117 Stem Cell Function In Vitro and In Vivo--Perspectives for Cardiac Stem Cell Therapy. Cell Physiol Biochem 2015;37:77-93. 


\section{Cellular Physiology Cell Physiol Biochem 2017;42:254-268

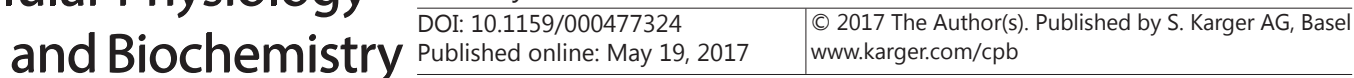

Lang et al.: Meta-Analysis: Cardiac Stem Cell Therapies in Mice

30 Zhang J, Wu Y, Chen A, Zhao Q: Mesenchymal stem cells promote cardiac muscle repair via enhanced neovascularization. Cell Physiol Biochem 2015;35:1219-1229.

31 Liu J, Wu P, Wang H, Wang Y, Du Y, Cheng W, Xu Z, Zhou N, Wang L, Yang Z: Necroptosis Induced by AdHGF Activates Endogenous C-Kit+ Cardiac Stem Cells and Promotes Cardiomyocyte Proliferation and Angiogenesis in the Infarcted Aged Heart. Cell Physiol Biochem 2016;40:847-860.

32 Gnecchi M, Zhang Z, Ni A, Dzau VJ: Paracrine mechanisms in adult stem cell signaling and therapy. Circ Res 2008;103:1204-1219.

33 Teng X, Chen L, Chen W, Yang J, Yang Z, Shen Z: Mesenchymal Stem Cell-Derived Exosomes Improve the Microenvironment of Infarcted Myocardium Contributing to Angiogenesis and Anti-Inflammation. Cell Physiol Biochem 2015;37:2415-2424.

-34 Holmes DI, Zachary I: The vascular endothelial growth factor (VEGF) family: angiogenic factors in health and disease. Genome Biol 2005;6:209.

-35 Reed JC, Doctor K, Rojas A, Zapata JM, Stehlik C, Fiorentino L, Damiano J, Roth W, Matsuzawa S, Newman R, Takayama S, Marusawa H, Xu F, Salvesen G, Godzik A, Group RG, Members GSL: Comparative analysis of apoptosis and inflammation genes of mice and humans. Genome Res 2003;13:1376-1388.

-36 Takao K, Miyakawa T: Genomic responses in mouse models greatly mimic human inflammatory diseases. Proc Natl Acad Sci U S A 2015;112:1167-1172.

-37 Patten RD, Hall-Porter MR: Small animal models of heart failure: development of novel therapies, past and present. Circ Heart Fail 2009;2:138-144.

-38 Jansen Of Lorkeers SJ, Eding JE, Vesterinen HM, van der Spoel TI, Sena ES, Duckers HJ, Doevendans PA, Macleod MR, Chamuleau SA: Similar effect of autologous and allogeneic cell therapy for ischemic heart disease: systematic review and meta-analysis of large animal studies. Circ Res 2015;116:80-86.

-39 Hare JM, Fishman JE, Gerstenblith G, DiFede Velazquez DL, Zambrano JP, Suncion VY, Tracy M, Ghersin E, Johnston PV, Brinker JA, Breton E, Davis-Sproul J, Schulman IH, Byrnes J, Mendizabal AM, Lowery MH, Rouy D, Altman P, Wong Po Foo C, Ruiz P, Amador A, Da Silva J, McNiece IK, Heldman AW, George R, Lardo A: Comparison of allogeneic vs autologous bone marrow-derived mesenchymal stem cells delivered by transendocardial injection in patients with ischemic cardiomyopathy: the POSEIDON randomized trial. JAMA 2012;308:2369-2379.

40 Bai Y, Sun T, Ye P: Age, gender and diabetic status are associated with effects of bone marrow cell therapy on recovery of left ventricular function after acute myocardial infarction: a systematic review and metaanalysis. Ageing Res Rev 2010;9:418-423.

41 Ostadal B, Ostadal P: Sex-based differences in cardiac ischaemic injury and protection: therapeutic implications. Br J Pharmacol 2014;171:541-554.

42 Barnabas O, Wang H, Gao XM: Role of estrogen in angiogenesis in cardiovascular diseases. J Geriatr Cardiol 2013;10:377-382.

43 Masuda H, Kalka C, Takahashi T, Yoshida M, Wada M, Kobori M, Itoh R, Iwaguro H, Eguchi M, Iwami Y, Tanaka R, Nakagawa Y, Sugimoto A, Ninomiya S, Hayashi S, Kato S, Asahara T: Estrogen-mediated endothelial progenitor cell biology and kinetics for physiological postnatal vasculogenesis. Circ Res 2007;101:598-606.

-44 Terrovitis J, Lautamaki R, Bonios M, Fox J, Engles JM, Yu J, Leppo MK, Pomper MG, Wahl RL, Seidel J, Tsui BM, Bengel FM, Abraham MR, Marban E: Noninvasive quantification and optimization of acute cell retention by in vivo positron emission tomography after intramyocardial cardiac-derived stem cell delivery. J Am Coll Cardiol 2009;54:1619-1626.

45 Cheng K, Li TS, Malliaras K, Davis DR, Zhang Y, Marban E: Magnetic targeting enhances engraftment and functional benefit of iron-labeled cardiosphere-derived cells in myocardial infarction. Circ Res 2010;106:1570-1581.

-46 Zimmermann WH, Melnychenko I, Wasmeier G, Didie M, Naito H, Nixdorff U, Hess A, Budinsky L, Brune K, Michaelis B, Dhein S, Schwoerer A, Ehmke H, Eschenhagen T: Engineered heart tissue grafts improve systolic and diastolic function in infarcted rat hearts. Nat Med 2006;12:452-458.

47 Sanganalmath SK, Bolli R: Cell therapy for heart failure: a comprehensive overview of experimental and clinical studies, current challenges, and future directions. Circ Res 2013;113:810-834. 


\section{Cellular Physiology Cell Physiol Biochem 2017;42:254-268

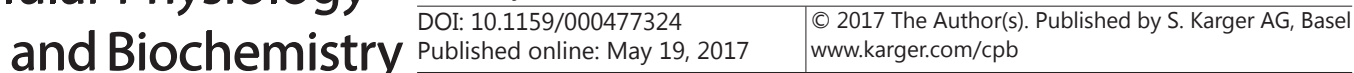

Lang et al.: Meta-Analysis: Cardiac Stem Cell Therapies in Mice

48 Lipinski MJ, Biondi-Zoccai GG, Abbate A, Khianey R, Sheiban I, Bartunek J, Vanderheyden M, Kim HS, Kang HJ, Strauer BE, Vetrovec GW: Impact of intracoronary cell therapy on left ventricular function in the setting of acute myocardial infarction: a collaborative systematic review and meta-analysis of controlled clinical trials. J Am Coll Cardiol 2007;50:1761-1767.

-49 de Jong R, Houtgraaf JH, Samiei S, Boersma E, Duckers HJ: Intracoronary stem cell infusion after acute myocardial infarction: a meta-analysis and update on clinical trials. Circ Cardiovasc Interv 2014;7:156-167.

50 Gyongyosi M, Wojakowski W, Lemarchand P, Lunde K, Tendera M, Bartunek J, Marban E, Assmus B, Henry TD, Traverse JH, Moye LA, Surder D, Corti R, Huikuri H, Miettinen J, Wohrle J, Obradovic S, Roncalli J, Malliaras K, Pokushalov E, Romanov A, Kastrup J, Bergmann MW, Atsma DE, Diederichsen A, Edes I, Benedek I, Benedek T, Pejkov H, Nyolczas N, Pavo N, Bergler-Klein J, Pavo IJ, Sylven C, Berti S, Navarese EP, Maurer G, Investigators A: Meta-Analysis of Cell-based CaRdiac stUdiEs (ACCRUE) in patients with acute myocardial infarction based on individual patient data. Circ Res 2015;116:1346-1360.

-51 Jeevanantham V, Butler M, Saad A, Abdel-Latif A, Zuba-Surma EK, Dawn B: Adult Bone Marrow Cell Therapy Improves Survival and Induces Long-Term Improvement in Cardiac Parameters A Systematic Review and Meta-Analysis. Circulation 2012;126:551-+.

52 Schaefer A, Zwadlo C, Fuchs M, Meyer GP, Lippolt P, Wollert KC, Drexler H: Long-term effects of intracoronary bone marrow cell transfer on diastolic function in patients after acute myocardial infarction: 5-year results from the randomized-controlled BOOST trial--an echocardiographic study. Eur J Echocardiogr 2010;11:165-171.

53 Singla DK, Hacker TA, Ma L, Douglas PS, Sullivan R, Lyons GE, Kamp TJ: Transplantation of embryonic stem cells into the infarcted mouse heart: formation of multiple cell types. J Mol Cell Cardiol 2006;40:195-200.

54 Nussbaum J, Minami E, Laflamme MA, Virag JA, Ware CB, Masino A, Muskheli V, Pabon L, Reinecke H, Murry CE: Transplantation of undifferentiated murine embryonic stem cells in the heart: teratoma formation and immune response. FASEB J 2007;21:1345-1357.

55 Burt RK, Chen YH, Verda L, Lucena C, Navale S, Johnson J, Han X, Lomasney J, Baker JM, Ngai KL, Kino A, Carr J, Kajstura J, Anversa P: Mitotically inactivated embryonic stem cells can be used as an in vivo feeder layer to nurse damaged myocardium after acute myocardial infarction: a preclinical study. Circ Res 2012;111:1286-1296.

56 Higgins JP, Thompson SG, Deeks JJ, Altman DG: Measuring inconsistency in meta-analyses. BMJ 2003;327:557-560.

57 Arai T, Kofidis T, Bulte JW, de Bruin J, Venook RD, Berry GJ, McConnell MV, Quertermous T, Robbins RC, Yang PC: Dual in vivo magnetic resonance evaluation of magnetically labeled mouse embryonic stem cells and cardiac function at 1.5 t. Magn Reson Med 2006;55:203-209.

58 Au KW, Liao SY, Lee YK, Lai WH, Ng KM, Chan YC, Yip MC, Ho CY, Wu EX, Li RA, Siu CW, Tse HF: Effects of iron oxide nanoparticles on cardiac differentiation of embryonic stem cells. Biochem Biophys Res Commun 2009;379:898-903.

59 Bai X, Yan Y, Song YH, Seidensticker M, Rabinovich B, Metzele R, Bankson JA, Vykoukal D, Alt E: Both cultured and freshly isolated adipose tissue-derived stem cells enhance cardiac function after acute myocardial infarction. Eur Heart J 2010;31:489-501.

-60 den Haan MC, Grauss RW, Smits AM, Winter EM, van Tuyn J, Pijnappels DA, Steendijk P, Gittenberger-De Groot AC, van der Laarse A, Fibbe WE, de Vries AA, Schalij MJ, Doevendans PA, Goumans MJ, Atsma DE: Cardiomyogenic differentiation-independent improvement of cardiac function by human cardiomyocyte progenitor cell injection in ischaemic mouse hearts. J Cell Mol Med 2012;16:1508-1521.

61 Drey F, Choi YH, Neef K, Ewert B, Tenbrock A, Treskes P, Bovenschulte H, Liakopoulos OJ, Brenkmann M, Stamm C, Wittwer T, Wahlers T: Noninvasive in vivo tracking of mesenchymal stem cells and evaluation of cell therapeutic effects in a murine model using a clinical 3.0 T MRI. Cell Transplant 2013;22:1971-1980.

-62 Grauss RW, Winter EM, van Tuyn J, Pijnappels DA, Steijn RV, Hogers B, van der Geest RJ, de Vries AA, Steendijk P, van der Laarse A, Gittenberger-de Groot AC, Schalij MJ, Atsma DE: Mesenchymal stem cells from ischemic heart disease patients improve left ventricular function after acute myocardial infarction. Am J Physiol Heart Circ Physiol 2007;293:H2438-2447.

-63 Grauss RW, van Tuyn J, Steendijk P, Winter EM, Pijnappels DA, Hogers B, Gittenberger-De Groot AC, van der Geest R, van der Laarse A, de Vries AA, Schalij MJ, Atsma DE: Forced myocardin expression enhances the therapeutic effect of human mesenchymal stem cells after transplantation in ischemic mouse hearts. Stem Cells 2008;26:1083-1093. 


\section{Cellular Physiology Cell Physiol Biochem 2017;42:254-268

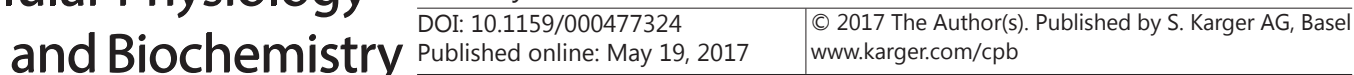

Lang et al.: Meta-Analysis: Cardiac Stem Cell Therapies in Mice

64 Huber BC, Ransohoff JD, Ransohoff KJ, Riegler J, Ebert A, Kodo K, Gong Y, Sanchez-Freire V, Dey D, Kooreman NG, Diecke S, Zhang WY, Odegaard J, Hu S, Gold JD, Robbins RC, Wu JC: Costimulation-adhesion blockade is superior to cyclosporine $\mathrm{A}$ and prednisone immunosuppressive therapy for preventing rejection of differentiated human embryonic stem cells following transplantation. Stem Cells 2013;31:2354-2363.

65 Kofidis T, Lebl DR, Swijnenburg RJ, Greeve JM, Klima U, Robbins RC: Allopurinol/uricase and ibuprofen enhance engraftment of cardiomyocyte-enriched human embryonic stem cells and improve cardiac function following myocardial injury. Eur J Cardiothorac Surg 2006;29:50-55.

66 Liao SY, Liu Y, Siu CW, Zhang Y, Lai WH, Au KW, Lee YK, Chan YC, Yip PM, Wu EX, Wu Y, Lau CP, Li RA, Tse HF: Proarrhythmic risk of embryonic stem cell-derived cardiomyocyte transplantation in infarcted myocardium. Heart Rhythm 2010;7:1852-1859.

67 Liu J, Narsinh KH, Lan F, Wang L, Nguyen PK, Hu S, Lee A, Han L, Gong Y, Huang M, Nag D, Rosenberg J, Chouldechova A, Robbins RC, Wu JC: Early stem cell engraftment predicts late cardiac functional recovery: preclinical insights from molecular imaging. Circ Cardiovasc Imaging 2012;5:481-490.

68 Ong SG, Huber BC, Lee WH, Kodo K, Ebert AD, Ma Y, Nguyen PK, Diecke S, Chen WY, Wu JC: Microfluidic Single-Cell Analysis of Transplanted Human Induced Pluripotent Stem Cell-Derived Cardiomyocytes After Acute Myocardial Infarction. Circulation 2015;132:762-771.

69 Paulis LE, Klein AM, Ghanem A, Geelen T, Coolen BF, Breitbach M, Zimmermann K, Nicolay K, Fleischmann BK, Roell W, Strijkers GJ: Embryonic cardiomyocyte, but not autologous stem cell transplantation, restricts infarct expansion, enhances ventricular function, and improves long-term survival. PLoS One 2013;8:e61510.

70 Rojas SV, Martens A, Zweigerdt R, Baraki H, Rathert C, Schecker N, Rojas-Hernandez S, Schwanke K, Martin U, Haverich A, Kutschka I: Transplantation Effectiveness of Induced Pluripotent Stem Cells Is Improved by a Fibrinogen Biomatrix in an Experimental Model of Ischemic Heart Failure. Tissue Eng Part A 2015;21:1991-2000.

71 Smits AM, van Laake LW, den Ouden K, Schreurs C, Szuhai K, van Echteld CJ, Mummery CL, Doevendans PA, Goumans MJ: Human cardiomyocyte progenitor cell transplantation preserves long-term function of the infarcted mouse myocardium. Cardiovasc Res 2009;83:527-535.

-72 van Laake LW, Passier R, den Ouden K, Schreurs C, Monshouwer-Kloots J, Ward-van Oostwaard D, van Echteld CJ, Doevendans PA, Mummery CL: Improvement of mouse cardiac function by hESC-derived cardiomyocytes correlates with vascularity but not graft size. Stem Cell Res 2009;3:106-112.

73 Wang J, Najjar A, Zhang S, Rabinovich B, Willerson JT, Gelovani JG, Yeh ET: Molecular imaging of mesenchymal stem cell: mechanistic insight into cardiac repair after experimental myocardial infarction. Circ Cardiovasc Imaging 2012;5:94-101.

74 Winter EM, van Oorschot AA, Hogers B, van der Graaf LM, Doevendans PA, Poelmann RE, Atsma DE, Gittenberger-de Groot AC, Goumans MJ: A new direction for cardiac regeneration therapy: application of synergistically acting epicardium-derived cells and cardiomyocyte progenitor cells. Circ Heart Fail 2009;2:643-653. 